\title{
MINERALOGICAL AND CHEMICAL COMPOSITION OF CFB FLY ASH DERIVED FROM CO-COMBUSTION OF XYLITE AND BIOMASS
}

\section{Koukouzas N. ${ }^{1}$, Hämäläinen $\mathrm{J}^{2}{ }^{2}$, Papanikolaou D. ${ }^{1}$, Tourunen A. ${ }^{2}$, and Jäntti T. ${ }^{3}$}

${ }^{1}$ Centre for Research and Technology Hellas, Institute for Solid Fuels Technology and Applications, $4^{\text {th }} \mathrm{km}$ of National Road Ptolemais - Kozani, GR - 502 00, Ptolemais, GREECE, tel: +3024630 53842,fax: +302463053843,e-mail:koukouzas@techp.demokritos.gr

${ }^{2}$ VTT Processes, Koivurannantie 1, P.O.Box 1603, 40101 Jyväskylä, Finland

${ }^{3}$ Foster Wheeler Energia Oy, Relanderinkatu 2, P.O.Box 201, 78201 Varkaus, Finland

\begin{abstract}
The chemical and mineralogical composition of fly ash samples collected from different parts of two Circulating Fluidised Bed (CFB) facilities has been investigated. The fuels used, were Greek xylite/subbituminous coal (from the Florina basin), Polish coal (from the Catowice region - Poland) and wood chips (Swedish conifer). The characterisation of the fly ash samples included chemical analyses, particle size distribution and X-ray diffraction. According to the chemical analyses the produced fly ashes are rich in $\mathrm{CaO}$. Moreover, $\mathrm{SiO}_{2}$ is the dominant oxide in fly ash with $\mathrm{Al}_{2} \mathrm{O}_{3}$ and $\mathrm{Fe}_{2} \mathrm{O}_{3}$ found in considerable quantities. Finally, results obtained by XRD showed that the major mineral phase of fly ash is quartz, while other mineral phases that are occurred are maghemite, hematite, periclase, rutile, gehlenite and anhydrite, while the aforementioned mineral phases were identified by scanning electron microscope (SEM).
\end{abstract}

Keywords: CFB fly ash, bituminous coal, xylite/subbituminous coal, wood chips.

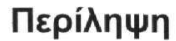

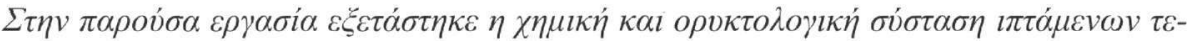

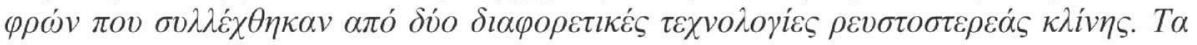

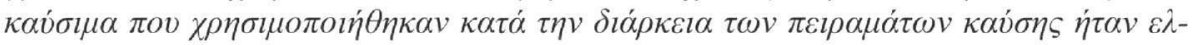

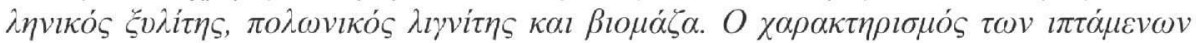

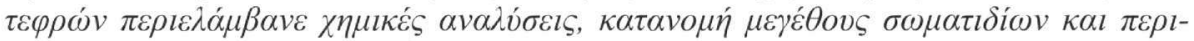

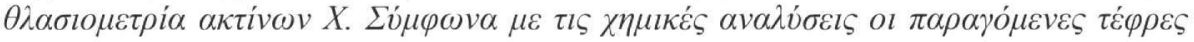

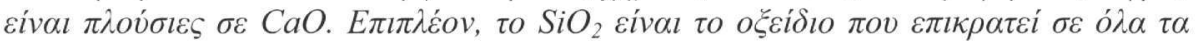

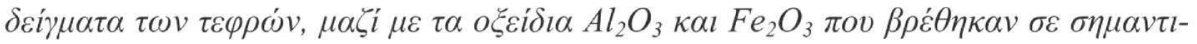

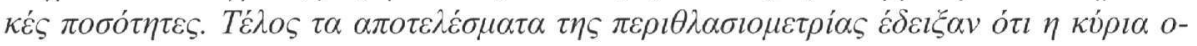

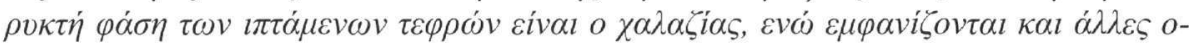

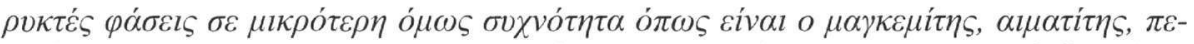

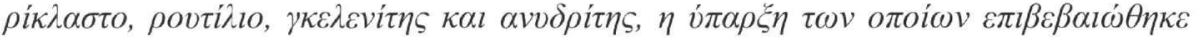

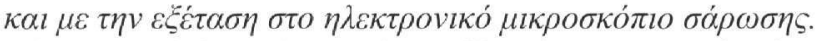

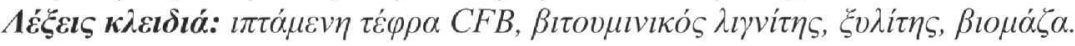




\section{Introduction}

In spite the fact that combustion of solid fuels using conventional combustion technologies is and will probably continue to be an important part of the heat and power generation systems, combustion of solid fuels applying more environmental friendly technologies, such as the Circulated Fluidised Bed (CFB) technology, continuously gains ground. Moreover, this technology has an other important advantage in comparison with conventional technologies; it is able to burn low quality fuels, such as lignite (xylite/subbituminous coal), alternative fuels such as biomass (wood chips) as well as blends of these fuels.

A result of the continuous development of the CFB technologies is that the amount of combustion by-products is steadily increasing. Fly ash can be either an industrial waste material and ecological nuisance, or a valuable raw material. For the latter purpose, its properties need to be defined precisely and controlled so that a uniform and reproducible material can be supplied. This paper describes a comprehensive study of some fly ash samples, with the intention of elucidating their chemical, physical, mineralogical and technical properties as an incentive to their utilization.

\section{Materials and analytical methods}

\subsection{Sampling}

The fly ash samples examined were produced from the combustion of different solid fuels in laboratory and pilot scale CFB boilers. Analyses of fly ash were carried out by means of XRF, partiCle size distribution, XRD, ICP and SEM. Finally the properties of the samples were related to the US standards (ASTM specifications).

The combustion experiments were carried out in the $50 \mathrm{~kW}$ lab scale boiler of VTT (Technical Research Centre of Finland), and the $12 \mathrm{MW}$ pilot scale boiler of Chalmers University (Sweden). The experimental facilities are following the flow chart as presented in Figure 1.

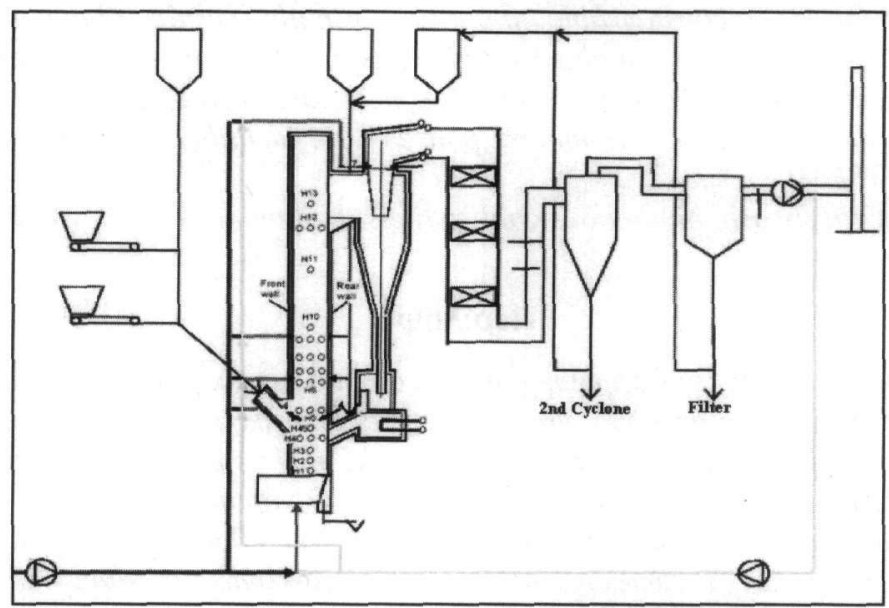

Figure 1 - Schematic diagram of the fluidised bed set-up

Combustion experiments were conducted using Polish coal, which is the main fossil fuel in WestEastern Europe (Katowise region in Poland), Greek xylite/lignite (Florina basin), the main fossil fuel in Greece, wood chips (Swedish conifer) as biomass, as well as blends of the aforementioned fuels in different rates. The ultimate and proximate analyses of the used fuels are presented in Table 1 and Table 2. 
Table 1 - Proximate Analysis of the fuels

\begin{tabular}{|c|c|c|c|}
\hline & Polish Bituminous Coal & Greek Xylite & Wood Chips \\
\hline Moisture & 1.9 & 36.5 & 4.6 \\
\hline Volatiles (\%, Dry Basis) & 29.33 & 41.67 & 80.10 \\
\hline Ash (\%, Dry Basis) & 12.96 & 38.36 & 1.14 \\
\hline Fixed Carbon (\%, Dry Basis) & 57.71 & 19.97 & 18.76 \\
\hline
\end{tabular}

Table 2 - Ultimate Analysis and Heating Values of the fuels (dry basis)

\begin{tabular}{|c|c|c|c|}
\hline & Polish Bituminous Coal & Greek Xylite & Wood Chips \\
\hline Carbon (\%) & 68.42 & 37.29 & 48.77 \\
\hline Hydrogen (\%) & 3.91 & 3.42 & 5.85 \\
\hline Nitrogen (\%) & 1.32 & 1.33 & 0.45 \\
\hline Oxygen (\%) & 12.69 & 17.96 & 43.79 \\
\hline Sulphur (\%) & 0.7 & 1.64 & 0 \\
\hline Gross Heating Value (kJ/kg) & 29171 & 17887 & 25154 \\
\hline Net Heating Value (kJ/kg) & 28330 & 17150 & 23899 \\
\hline
\end{tabular}

During the aforementioned experiments, fly ash samples from the same part of each facility were collected. These samples, the fuels combusted, the sampling point with the respective temperature are stated in Table 3 and Table 4.

Table 3 - Fly ash samples collected at VTT's facility

\begin{tabular}{|c|c|c|c|}
\hline Sample & Composition of fuels & Sampling Point & $\begin{array}{c}\text { Temperature } \\
\left({ }^{\circ} \mathbf{C}\right)\end{array}$ \\
\hline C1 & $100 \%$ Greek xylite & Second Cyclone & 662 \\
\hline C2 & $50 \%$ Wood Chips - 50\% Bituminous Coal & Second Cyclone & 735 \\
\hline C3 & $100 \%$ Wood Chips & Second Cyclone & 738 \\
\hline F1 & $100 \%$ Greek xylite & Fabric Filter & 144 \\
\hline F2 & $50 \%$ Wood Chips - 50\% Bituminous Coal & Fabric Filter & 161 \\
\hline F3 & $100 \%$ Wood Chips & Fabric Filter & 162 \\
\hline
\end{tabular}

Table 4 - Fly ash samples collected at Chalmers' facility

\begin{tabular}{|c|c|c|c|}
\hline Sample & Composition of fuels & Sampling Point & $\begin{array}{c}\text { Temperature } \\
\left({ }^{\circ} \mathbf{C}\right)\end{array}$ \\
\hline C4 & $100 \%$ Bituminous Coal & Second Cyclone & 155 \\
\hline C5 & $50 \%$ Wood Chips - 50\% Bituminous Coal & Second Cyclone & 155 \\
\hline C6 & $100 \%$ Wood Chips & Second Cyclone & 155 \\
\hline F4 & $100 \%$ Bituminous Coal & Fabric Filter & 155 \\
\hline F5 & $50 \%$ Wood Chips - 50\% Bituminous Coal & Fabric Filter & 155 \\
\hline F6 & $100 \%$ Wood Chips & Fabric Filter & 155 \\
\hline
\end{tabular}




\subsection{Bulk chemical analysis}

The major elements of the solid residues were determined with a Spectro X-Lab 2000 X-ray fluorescence (XRF) spectrometer.

Loss-on-ignition (LOI) tests were performed as follows: moisture, volatile matter, ash and fixed carbon measurements were conducted by a LECO TGA 501 Thermogravimetric Analyzer. The results were obtained on a dry basis. 0.5-2.5 g of each sample was heated from room temperature till $850{ }^{\circ} \mathrm{C}$. During the first minutes of each test, the sample was heated till $107^{\circ} \mathrm{C}$ at a rate of $15^{\circ} \mathrm{C} / \mathrm{min}$ in a nitrogen gas flow to stabilize the sample's weight (Brown and Dykstra, 1995). At this temperature the moisture content of the fly ash sample was received. The gas flow was automatically switched from nitrogen to oxygen and the chamber was then heated at a rate of $25{ }^{\circ} \mathrm{C} / \mathrm{min}$ until the sample reached $550{ }^{\circ} \mathrm{C}$. At this temperature data for the volatile matter was obtained. After that the temperature raised at $35{ }^{\circ} \mathrm{C} / \mathrm{min}$ till $850{ }^{\circ} \mathrm{C}$ where the ash content of the sample was received.

For the determination of trace elements a microwave-assisted acid digestion (MW-AD) followed by an Inductively Coupled Plasma-Optical Emission Spectrometry (ICP-OES) was applied.

\subsection{Particle Size Distribution}

The particle size of the ashes was measured with a Malvern Mastersizer-S particle size analyzer using the wet dispersion method in water.

\subsection{X-ray diffraction (XRD)}

The mineralogical composition of the fly ash samples was examined by XRD using a Siemens D 500 spectrometer with copper K $\alpha$ radiation.

\subsection{Scanning Electron Microscopy}

The morphology of the solid residues was observed using a JSM-6300 JEOL scanning electron microscope (SEM) operated with the typical accelerating voltage of $20 \mathrm{kV}$. The microscope was equipped with an Energy Dispersive X-ray Spectrometer with Oxford Link ISIS system.

The chemical and mineralogical analyses of the fly ash samples were carried out at the laboratories of the Centre for Research and Technology Hellas (CERTH).

\section{Results and discussion}

\subsection{Classification of the fly ash samples}

Based on the ASTM standards fly ash is classified according to the content of its major elements ( $\mathrm{Si}, \mathrm{Al}, \mathrm{Fe}$ and $\mathrm{Ca}$ ). ASTM C 618 defines three classes:

- Class $\mathrm{N}$ which includes raw of calcinated natural pozzolans with at least $70 \% \mathrm{SiO}_{2}, \mathrm{Al}_{2} \mathrm{O}_{3}$ and $\mathrm{Fe}_{2} \mathrm{O}_{3}$

- Class $\mathrm{F}$ which comprising ash produced from anthracite or bituminous coal combustion with at least $70 \% \mathrm{SiO}_{2}, \mathrm{Al}_{2} \mathrm{O}_{3}$ and $\mathrm{Fe}_{2} \mathrm{O}_{3}$

- Class $\mathrm{C}$ which comprising ash produced from lignite or sub-bituminous coal combustion with at least $50 \%$ but less than $70 \% \mathrm{SiO}_{2}, \mathrm{Al}_{2} \mathrm{O}_{3}$ and $\mathrm{Fe}_{2} \mathrm{O}_{3}$

Class $\mathrm{F}$ fly ashes usually contain less than $5 \% \mathrm{CaO}$, while fly ashes belonging to Class $\mathrm{C}$ contain a large proportion of $\mathrm{CaO}(10-35 \%)$.

From the chemical point of view the analysed ash samples are rich in $\mathrm{CaO}$, while the sum of the oxides $\mathrm{Al}_{2} \mathrm{O}_{3}, \mathrm{SiO}_{2}$ and $\mathrm{Fe}_{2} \mathrm{O}_{3}$ is over $50 \%$ but less than $70 \%$. This sum, as well as the concentration of $\mathrm{CaO}$ is shown in Table 5. According to the ASTM standard, the fly ashes are 
classified as class $\mathrm{C}$, except of sample $\mathrm{C} 1$ (xylite), which is associated with class $\mathrm{F}$. It is also worthwhile to mention that the bituminous coal produces fly ash of class $\mathrm{C}$.

Table 5 - Classification of fly ash samples

\begin{tabular}{|l|c|c|c|c|c|c|}
\hline & $\mathbf{C 1}$ & $\mathbf{C} 2$ & $\mathbf{C 3}$ & $\mathbf{C 4}$ & $\mathbf{C 5}$ & $\mathbf{C 6}$ \\
\hline $\mathrm{Al}_{2} \mathbf{O}_{3}+\mathrm{SiO}+\mathbf{F e}_{2} \mathbf{O}_{3}$ & 80.98 & 50.86 & 52.72 & 27.76 & 33.22 & 31.69 \\
\hline $\mathbf{C a O}$ & 5.73 & 14.19 & 19.59 & 9.58 & 13.76 & 41.16 \\
\hline & $\mathbf{F 1}$ & $\mathbf{F 2}$ & $\mathbf{F 3}$ & $\mathbf{F 4}$ & $\mathbf{F 5}$ & $\mathbf{F 6}$ \\
\hline $\mathbf{A l}_{2} \mathbf{O}_{3}+\mathbf{S i O}+\mathbf{F e}_{2} \mathbf{O}_{3}$ & 70.03 & 62.65 & 56.85 & 45.11 & 41.57 & 18.46 \\
\hline $\mathbf{C a O}$ & 12.53 & 12.68 & 15.04 & 8.67 & 18.13 & 41.70 \\
\hline
\end{tabular}

\subsection{Unburned carbon content}

The loss on ignition (LOI), which is a measurement of the amount of the unburned carbon remaining in the fly ash, is one of the most significant chemical properties of the samples analysed. The maximum LOI determined in these experiments, shown in Table 6 and Table 7, was F4 $(32.93 \%)$ and C4 (53.68 \%). The ASTM C-618 standard has an upper limit of $6 \%$, concerning fly ash utilization as a pozzolan in Portland cement. In general, low-carbon ashes are required because carbon may interfere with air entrainment by adsorbing entrainment additives, although the carbon content does not always have this effect (Foner et al. 1999). According to the aforementioned specification, good results are obtained by the fly ash samples originating from xylite/subbituminous coal and wood chips (samples F1, F6 and $\mathrm{C} 1, \mathrm{C} 3$ ). In compliance with the same ASTM standard, $\mathrm{SO}_{3}$ content should be lower than $5 \%$. In this case only the sample $\mathrm{C} 1$ from the second cyclone meets this requirement.

\subsection{Chemical composition}

$\mathrm{Al}_{2} \mathrm{O}_{3}$ occurs in higher amounts in all samples from the fabric filter except of $\mathrm{F} 6$ (wood chips) and in all samples from the second cyclone (Table 6 and Table 7). This is also in accordance with literature review (Steenari and Lindqvist 1999). The addition of coal in the fuel mixture enriches the ash composition in Fe. Oxides containing this element $\left(\mathrm{Fe}_{2} \mathrm{O}_{3}\right)$ were also identified by means of XRD. This oxide was present as hematite or maghemite in almost all samples examined, except of F6 (wood chips) and C6 (wood chips), which contained approximately only $2.5 \%$ of $\mathrm{Fe}_{2} \mathrm{O}_{3}$. On the other hand wood fly ash is rich in phosphorous, as seen in the aforementioned tables. This phosphorous originates from the raw material (wood) used (Steenari and Lindqvist 1999). Consequently, $\mathrm{P}_{2} \mathrm{O}_{5}$ was significant enriched in the fly ash samples originating from this material. Moreover, calcium is also an important component in wood. As expected, the Ca levels of fly ash from co-combustion of wood with coal were lower than those of fly ash coming from the combustion of wood. It is generally noticed that when the proportion of wood in the coal - wood mixture is increased, the concentration of alkalis ( $\mathrm{Na}$ and especially $\mathrm{K}$ ) is also elevated.

Table 6 - Ash composition (\%) of the second cyclone samples as determined by XRF-analysis

\begin{tabular}{|c|c|c|c|c|c|c|}
\hline & $\mathbf{C 1}$ & $\mathbf{C 2}$ & $\mathbf{C 3}$ & $\mathbf{C 4}$ & $\mathbf{C 5}$ & $\mathbf{C 6}$ \\
\hline $\mathbf{S i O}_{\mathbf{2}}$ & 47.80 & 28.05 & 29.20 & 14.57 & 18.72 & 20.07 \\
\hline $\mathbf{F e}_{\mathbf{2}} \mathbf{O}_{3}$ & 9.06 & 7.70 & 8.89 & 4.74 & 5.53 & 2.36 \\
\hline $\mathbf{A l}_{\mathbf{2}} \mathbf{O}_{\mathbf{3}}$ & 24.12 & 15.11 & 14.63 & 8.45 & 8.97 & 9.26 \\
\hline
\end{tabular}




\begin{tabular}{|c|c|c|c|c|c|c|}
\hline $\mathbf{T i O}_{2}$ & 0.98 & 0.48 & 0.39 & 0.29 & 0.27 & 0.05 \\
\hline $\mathbf{C a O}$ & 5.73 & 14.19 & 19.59 & 9.58 & 13.76 & 41.16 \\
\hline $\mathrm{MgO}$ & 3.64 & 5.00 & 5.70 & 2.99 & 3.89 & 4.47 \\
\hline $\mathbf{S O}_{3}$ & 3.80 & 9.65 & 13.23 & 3.82 & 4.81 & 4.02 \\
\hline $\mathbf{P}_{\mathbf{2}} \mathbf{O}_{\mathbf{5}}$ & 0.50 & 0.73 & 1.03 & 0.31 & 0.78 & 2.34 \\
\hline $\mathrm{Na}_{\mathbf{2}} \mathbf{O}$ & 0.28 & 1.46 & 1.95 & 1.10 & 1.82 & 0.63 \\
\hline $\mathbf{K}_{\mathbf{2}} \mathbf{O}$ & 3.13 & 2.23 & 2.96 & 0.91 & 3.07 & 5.57 \\
\hline $\mathbf{L O I}$ & 1.19 & 16.24 & 2.64 & 53.68 & 33.36 & 10.51 \\
\hline Total & 100.23 & 100.84 & 100.24 & 100.44 & 99.98 & 100.44 \\
\hline
\end{tabular}

Table 7 - Ash composition (\%) of the filter samples as determined by XRF-analysis

\begin{tabular}{|c|c|c|c|c|c|c|}
\hline & F1 & F2 & F3 & F4 & F5 & F6 \\
\hline $\mathbf{S i O}_{2}$ & 40.33 & 36.58 & 32.96 & 23.35 & 22.81 & 13.39 \\
\hline $\mathbf{F e}_{2} \mathbf{O}_{3}$ & 8.11 & 6.53 & 6.01 & 6.34 & 4.69 & 2.46 \\
\hline $\mathbf{A l}_{2} \mathbf{O}_{3}$ & 21.59 & 19.54 & 17.88 & 15.42 & 14.07 & 2.61 \\
\hline $\mathbf{T i O}_{2}$ & 1.34 & 1.06 & 0.90 & 0.77 & 0.69 & 0.03 \\
\hline $\mathbf{C a O}$ & 12.53 & 12.68 & 15.04 & 8.67 & 18.13 & 41.70 \\
\hline $\mathbf{M g O}$ & 4.10 & 3.58 & 4.18 & 4.71 & 5.81 & 8.10 \\
\hline $\mathbf{S O}$ & 8.09 & 7.51 & 8.98 & 3.37 & 5.86 & 10.08 \\
\hline $\mathbf{P}_{2} \mathbf{O}_{\mathbf{5}}$ & 0.71 & 0.92 & 1.37 & 0.87 & 2.55 & 4.67 \\
\hline $\mathbf{N a}_{\mathbf{2}} \mathbf{O}$ & 0.30 & 0.63 & 1.23 & 2.17 & 0.88 & 2.75 \\
\hline $\mathbf{K}_{2} \mathbf{O}$ & 2.25 & 2.05 & 2.26 & 1.65 & 6.41 & 12.08 \\
\hline $\mathbf{L O I}$ & 1.10 & 9.34 & 9.51 & 32.93 & 18.15 & 2.17 \\
\hline Total & 100.35 & 100.42 & 100.32 & 100.25 & 100.05 & 100.04 \\
\hline
\end{tabular}

In the following table (Table 8) the trace element concentrations determined by ICP-OES are presented:

Table 8 - Concentration $(\mathrm{mg} / \mathrm{kg})$ of trace elements in the fly ash samples

\begin{tabular}{|c|c|c|c|c|c|c|}
\hline & C1 & C2 & C3 & C4 & C5 & C6 \\
\hline As & $<5$ & $<5$ & $<5$ & $<5$ & $<5$ & $<5$ \\
\hline Cr & $160 \pm 13$ & $145 \pm 15$ & $180 \pm 16$ & $32 \pm 3$ & $72 \pm 7$ & $20 \pm 2$ \\
\hline Co & $23 \pm 2$ & $18 \pm 2$ & $22 \pm 2$ & $8.2 \pm 0.8$ & $8.7 \pm 0.8$ & $<5$ \\
\hline & $\mathbf{F 1}$ & $\mathbf{F 2}$ & $\mathbf{F 3}$ & $\mathbf{F 4}$ & $\mathbf{F 5}$ & F6 \\
\hline As & $36 \pm 3.5$ & $43 \pm 4$ & $20 \pm 2$ & $<5$ & $<5$ & $<5$ \\
\hline Cr & $190 \pm 17$ & $182 \pm 16$ & $180 \pm 16$ & $100 \pm 8$ & $115 \pm 9$ & $29.5 \pm 3$ \\
\hline Co & $31 \pm 3$ & $43.6 \pm 4$ & $48 \pm 4$ & $42.5 \pm 4$ & $39.5 \pm 4$ & $7.4 \pm 0.7$ \\
\hline
\end{tabular}

According to the literature (Steenari and Lindqvist 1999), the concentration of trace elements of the coal ash from fluidised bed ranges between $1-300 \mathrm{mg} / \mathrm{kg}$, while the concentration of $\mathrm{Cr}$ ranges between $1-500 \mathrm{mg} / \mathrm{kg}$. Co concentrations range in the same orders of magnitude. Therefore, 
compared to coal ash from fluidised bed combustion, the levels of $\mathrm{As}$ and $\mathrm{Cr}$ in many of the ashes included in this study seem rather low, especially the As content.

The concentration of As in xylite fly ash is attributed to the soil parent material, especially the earth crust which is enriched in this element. In these samples the elevated amounts of As could be due to the contact of fly ash with flue gases, the hydraulic conductivity (low in fly ash) and the surface area.

It appears that (Baba and Usmen 2006) most of the As in coal is associated with pyrite. In the majority of coals studied, As is primarily associated with massive or late-stage pyrite. In some cases As is associated with fine-grained pyrite and other sulphide minerals (calcophiles) (Martinez-Tarazona and Spears 1996). Furthermore, As is significantly concentrated in the small sized particles and its concentration is increased with the increasing of the surface area (MartinezTarazona and Spears 1996).

The concentrations of $\mathrm{As}, \mathrm{Cr}$ and $\mathrm{Co}$ are similar in the second cyclones and in the fabric filters for the combustion of the same fuels. The exception is As with higher concentrations in the fly ashes from the VTT facility. This difference could be attributed to differences in the behaviour of the flue gases in the two facilities compared.

Although some times the relatively high concentration of $\mathrm{Cr}$ could be metallic and associated with stainless steel (Goodarzi 2006), in the present case is interpreted as original and related to the geological setting of the coal deposits. Thus, it is known that the lignites from northern Greece are enriched in $\mathrm{Cr}$ due to the influence of the high contents of this element in the ultrabasic rocks of the area (Georgakopoulos et al. 2002a, 2002b).

A potential benefit (Strock and Stehouwer 2004) of fly ash as a soil amendment is as a source of nutrient elements for plant growth. Of the macronutrients (nitrogen, phosphorus, potassium, calcium, magnesium, and sulphur), fly ash can supply sulphur, especially if it comes from the combustion of wood chips.

Besides the geochemical characteristics of trace element distribution in coals, emission of trace elements into the gaseous phase considerably depends on the condition of coal combustion (especially temperature) and effectiveness of the cleaning systems of the gases emitted. It should be noted that most of the trace elements present in gaseous emissions are not in a true gas state, but are retained on the surface of solid particles (in ash). As a result, many elements end up in silicate melts or condense onto particle surface; only a few trace elements are likely emitted into the atmosphere as gaseous compounds.

Furthermore, the distribution and concentration of trace elements in coal ashes as well as the mechanism of their enrichment are also closely related to furnace type and combustion manner. That is mainly because the combustion furnace type and combustion manner are closely related to the degree of coal combustion, combustion temperature, and combustion sufficiency. If coal is sufficiently combusted in the furnace, the contents of incompletely combusted coal particles would be low in ashes, and hence the trace elements present in organic matter in coal would be released as smoke dust during coal combustion in increasing amounts, their contents in ashes would be reduced, and the concentrations of the trace elements entering into atmosphere would increase.

As a result the concentration of $\mathrm{Cr}$ and $\mathrm{Co}$ in sample $\mathrm{C} 3$ is higher compared to $\mathrm{C} 6$. Both originate from the combustion of the same fuel (wood chips), but collected at different temperatures, $\mathrm{C} 3$ at $738{ }^{\circ} \mathrm{C}$ and $\mathrm{C} 6$ at $155^{\circ} \mathrm{C}$. Moreover they are produced at different combustion furnace types. Sample C3 was produced at a $50 \mathrm{~kW}$ laboratory scale boiler and C6 at a $12 \mathrm{MW}$ pilot scale boiler.

\subsection{Particle Size Distribution}

Particle size distribution (Gutierrez et al. 1993) of fly ashes is of particular interest when the material is used as a substitute for a portion of cement in concrete and in soil-stabilization mixtures. 
Potential effects influenced by particle size distribution are related to: rheology, floe structure of the cement paste, permeability of the hard paste and rate of strength gain. Particle characterization of fly ashes is also important for the recovery of metals. Leachability of the smallest particles is easier as they are more reactive, and in addition trace elements tend to concentrate in the finest particles (Liu et al. 2004). Taking into account that the upgrading of fly ashes has economic limitations, a good characterization of the particle is essential to the process of metal recovery.

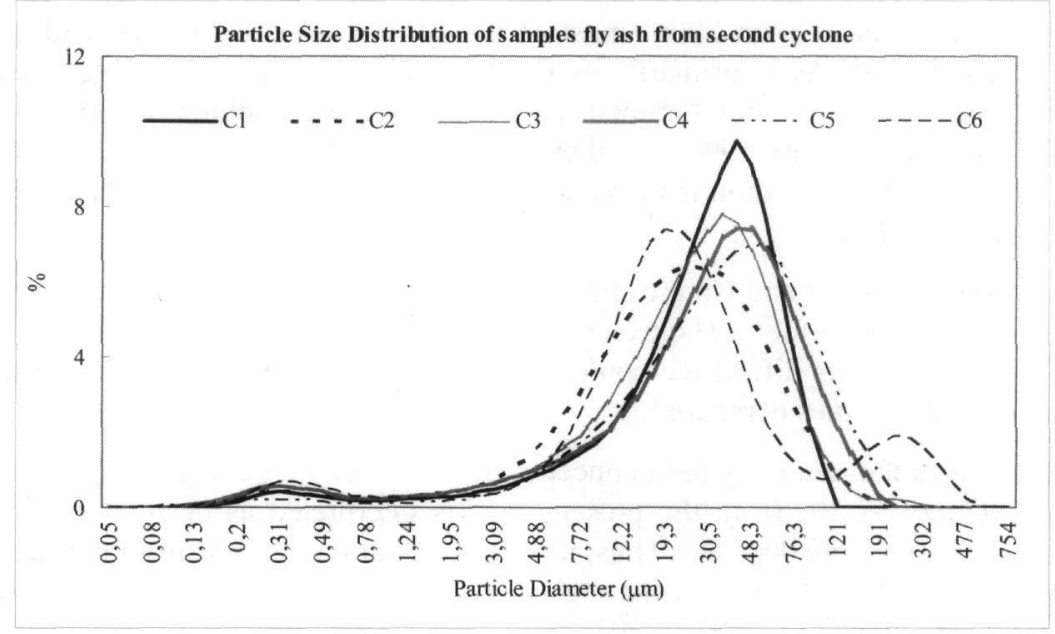

Figure 2 - Particle size distribution of samples from the second cyclone

The particle size distribution of fly ashes is usually between $1 \mu \mathrm{m}$ and $200 \mu \mathrm{m}$, although coarser particles may exist especially if the ashes come from lignite. Moreover, according to the literature (Jankowski et al. 2005), the fly ashes derived from CFB technologies contain smaller particle than the fly ashes coming from conventional combustion technologies.

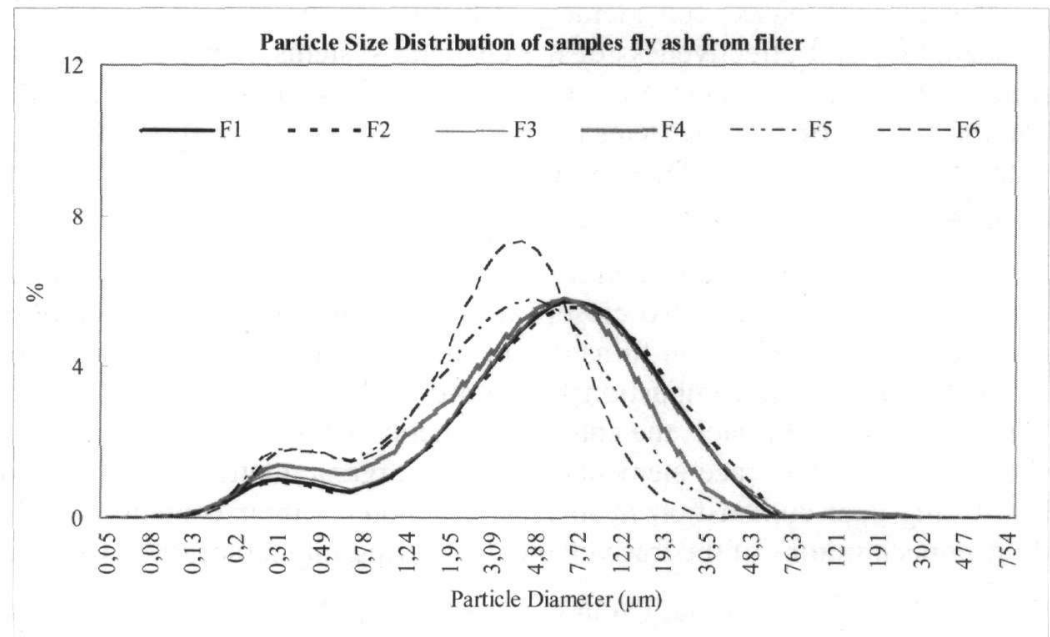

Figure 3 - Particle size distribution of samples from the filter

Figure 2 and Figure 3 present the mean particle size distribution of the filter and second cyclone samples. The results show that the particle size distribution of the fly ashes ranges between $1 \mu \mathrm{m}$ and $200 \mu \mathrm{m}$. Moreover a second peak occurs in the size distribution of all samples, in the range between 0.1 and $1 \mu \mathrm{m}$. 
Concerning the composition of fuels used, it is remarked that when the proportion of biomass (wood chips) in the fuel mixture was increased, the peak shifted to a smaller particle size (Fig. 2). This fact leads to the conclusion that, the size of fly ash particles is reduced when the proportion of biomass in the fuel mixture is increased.

Figure 3 depicts the particle size distribution of ashes from the fabric filter. As it can be seen samples F1, F2, F3 have a coarser particle size than F4, F5 and F6. This result is due to the different combustion temperatures applied (Table 3 and Table 4) and the different fuel blends used.

In general, most naturally existing elements can be found in fly ash and a number of researchers agree that many of the trace elements in fly ash show a definite concentration trend with decreasing particle size. Concentrations of arsenic, cadmium, copper, gallium, molybdenum, lead, sulphur, antimony, selenium, thallium and zinc have been reported to increase with decreasing particle size. This is why the samples F1, F2 and F3 which are of a smaller particle size than C1, $\mathrm{C} 2$ and $\mathrm{C} 3$, all coming from the same combustion facility, have an elevated amount of $\mathrm{As}, \mathrm{Cr}$ and $\mathrm{Co}$, as already described in the former section concerning the trace elements.

\subsection{X-ray diffraction (XRD)}

Mineralogical analyses of the fly ash samples were accomplished with the identification of crystalline phases using XRD. Although the samples are principally composed of glassy material, several distinct peaks were observed and the following minerals identified: quartz, hematite anhydrite and periclase. Some additional peaks on the diffractograms were attributed to maghemite, portlandite, gehlenite, magnesioferrite, lime, sylvite and rutile, which occurred in some samples.

The results of the mineralogical composition of these samples, obtained from the X-ray patterns, are presented in table 9.

Table 9 - Mineral phases in the fly ash samples

\begin{tabular}{|c|c|c|c|c|c|c|c|c|c|c|c|c|}
\hline Mineral Phases & F1 & F2 & F3 & F4 & F5 & F6 & C1 & $\mathrm{C} 2$ & $\mathrm{C3}$ & C4 & C5 & C6 \\
\hline Quartz- $\mathrm{SiO}_{2}$ & $\mathrm{X}$ & $\mathrm{X}$ & $\mathrm{X}$ & $\mathrm{X}$ & & & $\mathrm{X}$ & $\mathrm{X}$ & $\mathrm{X}$ & $\mathrm{X}$ & $\mathrm{X}$ & $\mathrm{X}$ \\
\hline Maghemite - $\mathrm{Fe}_{2} \mathrm{O}_{3}$ & & $\mathrm{X}$ & & & $\mathrm{X}$ & & $\mathrm{X}$ & & & & & \\
\hline Hematite - $\mathrm{Fe}_{2} \mathrm{O}_{3}$ & $\mathrm{X}$ & $\mathrm{X}$ & $\mathrm{X}$ & & & & $\mathrm{X}$ & $\mathrm{X}$ & $X$ & $\mathrm{X}$ & $X$ & \\
\hline Anhydrite - $\mathrm{CaSO}_{4}$ & $\mathrm{X}$ & $\mathrm{X}$ & $\mathrm{X}$ & $\mathrm{X}$ & & & $\mathrm{X}$ & $X$ & $\mathrm{X}$ & $\mathrm{X}$ & $\mathrm{X}$ & \\
\hline Periclase - MgO & & & $\mathrm{X}$ & $\mathrm{X}$ & $X$ & $\mathrm{X}$ & & $\mathrm{X}$ & $\mathrm{X}$ & $\mathrm{X}$ & $\mathrm{X}$ & $X$ \\
\hline $\begin{array}{l}\text { Portlandite - } \\
\mathrm{Ca}(\mathrm{OH})_{2}\end{array}$ & & & & & & $\mathrm{X}$ & & & $\mathrm{X}$ & & & $\mathrm{X}$ \\
\hline $\begin{array}{l}\text { Gehlenite - } \\
\mathrm{Ca}_{2} \mathrm{Al}(\mathrm{Al}, \mathrm{Si})_{2} \mathrm{O}_{7}\end{array}$ & & & & & $\mathrm{X}$ & & & & & & & \\
\hline $\begin{array}{l}\text { Magnesioferrite - } \\
\mathrm{MgFe}_{2} \mathrm{O}_{4}\end{array}$ & & & & $\mathrm{X}$ & & & & & & & & \\
\hline Lime $-\mathrm{CaO}$ & & & & & & $\mathrm{X}$ & & & & & $\mathrm{X}$ & \\
\hline Sylvite - KCl & & & & & & $\mathrm{X}$ & & & & & & \\
\hline Rutile $-\mathrm{TiO}_{2}$ & X & & & & & & & & & & & \\
\hline
\end{tabular}

" $\mathrm{X}$ " denotes that the corresponding crystalline phase was identified using XRD 


\subsection{Phase-mineral composition and genetic features}

According to the aforementioned table (Table 7) almost all ash samples contain quartz, which is a mineral that can be considered as primary, especially in cases where ash samples originate from fuels such as bituminous coal and xylite/subbituminous coal, which contain large amounts of silica dioxide. In addition, the presence of quartz in samples originating from wood chips can be justified by the use of sand as a bed material in the CFB boiler.

Except of quartz, the majority of the samples contain hematite which is also a mineral that can be considered as primary, especially in cases where bituminous coal is used. This type of coal has higher percentages of ferric oxide in comparison with xylite/subbituminous coal and the wood chips used (Table 6 and Table 7). Moreover, hematite can be considered as a secondary mineral since it can be formed from calcite-pyrite reactions. Therefore, its presence in samples could either be due to the fuel used or to the reactions occurring during the combustion process.

In contrast to hematite, maghemite (secondary origin) is not present in all fly ash samples. It is formed through the oxidation of magnetite at low temperatures and its presence in the fly ash should be correlated to the occurrence of magnetite in the raw material.

Another mineral, which is present in the majority of the samples, is anhydrite. Anhydrite is a mineral that is formed by dehydration of bassanite $\left(\mathrm{CaSO}_{4} \cdot 1 / 2 \mathrm{H}_{2} \mathrm{O}\right)$ which is of primary origin or formed by calcite - pyrite reactions at temperatures higher than $300{ }^{\circ} \mathrm{C}$. Although the fly ash from wood chips is abundant in calcium, anhydrite is absent from these samples. This is probably attributed to the low concentration of sulphur or to the participation of calcium in the formation of other minerals, such as lime or portlandite. In contrast to the other minerals (quartz, hematite and maghemite) anhydrite is soluble and will react with water to form gypsum or ettringite, a nondesirable mineral in the cement or concrete production.

In the case where the samples do not contain anhydrite, portlandite is present. This mineral appears at low or medium combustion temperatures (above $675^{\circ} \mathrm{C}$ ) via calcite heating, which can be considered as a primary mineral.

Another mineral identified by XRD is periclase (secondary mineral) which is formed from the decomposition of dolomite $\left(\mathrm{CaMg}\left(\mathrm{CO}_{3}\right)_{2}\right)$ through magnesite. It does not appear in samples which originate from xylite/subbituminous coal. Analysing the fuels, dolomite was identified by XRD only in the bituminous coal; therefore the formation of periclase in the respective fly ash samples is possible. In addition, the presence of periclase in these samples is confirmed by the elevated concentration of $\mathrm{MgO}$ (Table 6 and Table 7).

Only the sample derived from the combustion of bituminous coal (F4) contains magnesioferrite. The presence of hematite in combination with the presence of periclase could lead to the formation of this mineral. On the one hand, the absence of hematite may be due to its participation in the formation of magnesioferrite. On the other hand the presence of periclase in the same sample may be due to the high amount of this mineral which did not fully participate in the formation of magnesioferrite.

In addition, only sample F1 (xylite) contains rutile, which is a mineral of secondary origin. This is corroborated by the XRF analysis (Table 7) which shows that F1 contains a relatively higher concentration of $\mathrm{Ti}_{2} \mathrm{O}$ in comparison to the other samples.

Finally, sample F5 contains gehlenite, which originates from carbonate-silicate-spinel reactions, while sample F6 contains sylvite. The presence of gehlenite leads to the assumption that calcium from wood chips and silica dioxide from coal in this proportion is able to form this mineral, while the presence of sylvite is confirmed by the high amounts of potassium in the same sample (Table 7). 


\subsection{Scanning Electron Microscope (SEM)}

Representative samples were analysed by SEM EDX. This technique gives the location of elements in the region being scanned. The distribution of each element can be easily detected in the fly ash samples.

Each sample was mounted into specimen holders, carbon coated and analysed taking backscattered - as well as secondary electron images. The chemical composition of the particulates and the homogenous groundmass is determined from the collection of the energy dispersive spectra (EDX) of the X-rays that are generated from the particle by the electron beam.

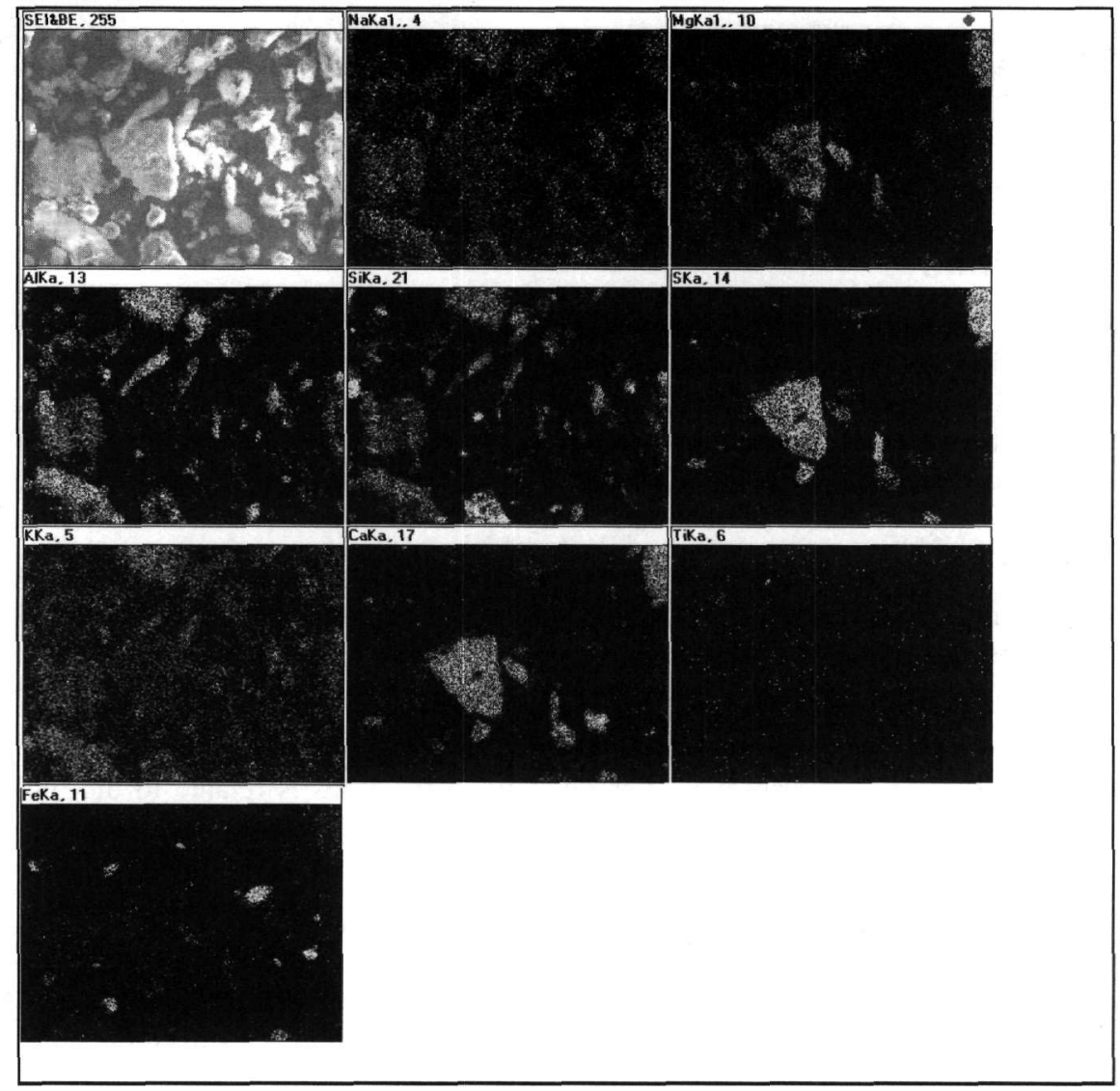

Figure 4 - Mapped region of fly ash sample C2

Morphology, texture and chemistry of the samples were analysed. Examination under the scanning electron microscope showed that the fly ash samples are different in comparison with the conventional fly ash. The morphology of conventional fly ashes such as the presence of cenospheres and plerospheres varies within the examined fly ashes. Moreover, the majority of the quartz crystals remains and is present as angular particles due to the relatively low temperature in the Circulating Fluidised Bed furnace. In addition the CFB fly ashes are present as subangular forms as they contain bi-mineral and multi-mineralogical phases and quartz is mixed with calcium and aluminosilicate phases.

Figure 4 shows a secondary electron image of a specified mapped region followed by nine elements chosen ( $\mathrm{Na}, \mathrm{Mg}, \mathrm{Al}, \mathrm{Si}, \mathrm{S}, \mathrm{K}, \mathrm{Ca}, \mathrm{Ti}$ and $\mathrm{Fe}$ ) such that the fly ash particles could be identified in the SEM photos. 
The majority of mineral phases, which were identified by XRD, were also examined by SEM. Some of the most common mineral phases are shown in Figure 5.

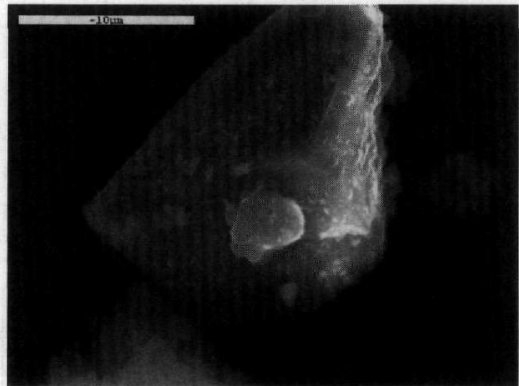

Figure 5a - The mineral quartz in sample C3

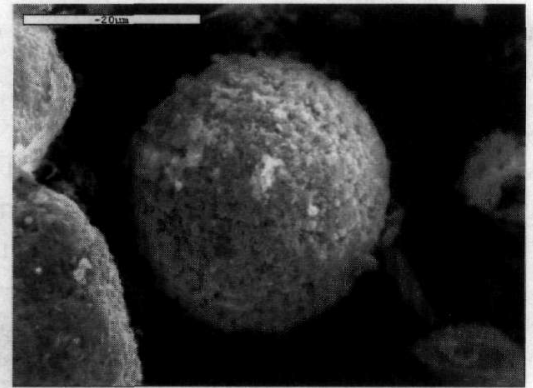

Figure $5 b$ - The mineral hematite in sample $\mathrm{C} 1$

\section{Conclusions}

Compared to fly ash from combustion of wood chips, the co-combustion ashes studied had lower contents of calcium, potassium and magnesium. The admixture of coal to the wood fuel adds aluminium and iron to the ash. The trace metal levels were generally in the same ranges as for wood fly ash. The trace elements which may cause some concern are As and $\mathrm{Cr}$ in the case of sample F1 (xylite) and F2 (xylite/wood chips), which in addition are of small particle size. As aforementioned, many of the trace elements in fly ash show a definite concentration trend with decreasing particle size.

On the other hand fly ash deriving from the combustion of pure xylite/subbituminous coal and pure wood chips has a low LOI level. If the $\mathrm{SO}_{3}$ content is taken additionally into account $\left(\mathrm{SO}_{3}<5 \%\right)$, then the most attractive fly ash to the cement industry is $\mathrm{Cl}$ (xylite), collected at the second cyclone.

Moreover, the particle size distribution of the examined fly ashes is related to the fuels burned. The higher the percentage of biomass in the blends, the smaller the ash particle size.

Regarding the mineralogical composition of the fly ash samples, it appears that the composition of the samples depends both on the used fuels and the combustion temperature. The presence of minerals such as anhydrite and portlandite is more possible when the used fuels contain calcium; therefore fly ash derived from wood chips contains the aforementioned minerals. Also, the occurrence of minerals such as sylvite is noticed when the fly ash derives from the combustion of biomass, due to the higher concentration of alkalis in this fuel.

The results obtained in this study showed that fly ash from co-combustion of wood with other fuels such as xylite/subbituminous coal and bituminous coal may have chemical characteristics depending on the furnace type, the combustion manner as well as the effectiveness of the cleaning system of the gases emitted. That is mainly because the combustion furnace type and combustion manner are closely related to the degree of coal combustion, combustion temperature, and combustion sufficiency.

It is likely that ash from xylite/subbituminous coal, apart from its utilization in the cement industry, can be applied in soil fertilizing in moderate doses. However, the quality of xylite/subbituminous coal ash as well as xylite/wood ash must be monitored closely before its use in order to ensure that the levels of toxic trace elements are not too high. 


\section{Acknowledgments}

The authors gratefully acknowledge financial support from the European Commission, Research Fund for Coal and Steel, under contract RFC-CR-03001. Prof. F. Johnson is also acknowledged for the combustion experiments performed in Chalmers University. The support of $\mathrm{Mr}$ Chrisovalantis Ketikidis and Ms Asimina Tremouli from Centre for Research and Technology Hellas, Institute for Solid Fuels Technology and Applications is also acknowledged.

\section{References}

ASTM, 1996. In Annual book of ASTM standards, vol. 4.02: Concrete and aggregates. Philadelphia, PA: American Society for Testing and Materials, 293.

Baba, A, and Usmen, M. A., 2006. Effects of fly ash from coal-burning electrical utilities on ecosystem and utilization of fly ash. In A. Baba, K.W. Howard and O. Gunduz (eds), Groundwater and Ecosystems, IV. Earth and Environmental Sciences, vol. 70 15-31 pp., NATO Science Series.

Brown, C.R., and Dykstra, J., 1995. Systematic errors in the use of loss-on-ignition to measure unburned carbon in fly ash, Fuel, 74, 570-574.

Foner, H.A., Robl, T.L., Hower, J.C., and Graham, U.M., 1999. Characterization of fly ash from Israel with reference to its possible utilization, Fuel, 78, 215-223.

Georgakopoulos, A., Filippidis, A., Kassoli-Fournaraki, A., Iodanidis, A., Fernández-Turiel, J.L., Llorens, J.F., and Gimeno, D., 2002a. Environmentally important elements in fly ashes and their leachates of the Power Stations of Greece, Energy Sources, 24(1), 83-91.

Georgakopoulos, A., Filippidis, A., Kassoli-Fournaraki, A., Fernández-Turiel, J.L., Llorens, J.F., and Mousty, F., 2002b. Leachability of major and trace elements of fly ash from Ptolemais Power Station, Northern Greece, Energy Sources, 24(2), 103-113.

Goodarzi, F., 2006. Morphology and chemistry of fine particles emitted from a Canadian coalfired power plant, Fuel, 85, 273-280.

Gutierrez, B., Pazos, C., and Coca, J., 1993. Characterization and leaching of coal fly ash, 1993, Waste Management \& Research, 11, 279-286.

Jankowski, J., Ward, C.R., and French, D., 2005. The Heavy Metal Leaching Behaviour of Australian Fly Ashes, submitted for consideration in the 2005 World of Coal Ash, Lexington, Kentucky USA.

Liu, G., Zhang, H., Gao, L., Zheng, L., and Peng, Z., 2004, Petrological and mineralogical characterizations and chemical composition of coal ashes from power plants in Yanzhou mining district, China, Fuel Processing Technology, 85, 1635-1646.

Martinez-Tarazona, M.R., and Spears, D.A., 1996. The fate of trace elements and bulk minerals in pulverized coal combustion in a power station, Fuel Process Technol, 47, 79-92.

Steenari, B.M., and Lindqvist, O., 1999. Fly ash characteristics in co-combustion of wood with coal, oil or peat, Fuel, 78, 479-488.

Strock, N.G., and Stehouwer, R.C., 2004. Soil additives and soil amendments. Chapter 10, In W.B. White (ed.) Coal ash beneficial use in mine reclamation and mine drainage remediation in Pennsylvania, Harrisburg, PA, 302-315pp. 